\title{
Empowerment of Posyandu Cadres in Early Detection of Child Growth Problems: Optimization of KIA Books
}

\author{
Alfi Muntafiah ${ }^{1 *}$, Octavia Permata Sari ${ }^{1}$, Nor Sri Inayati ${ }^{1}$, Qodri Santosa ${ }^{2}$ \\ ${ }^{1}$ Department of Biochemistry, Faculty of Medicine, Universitas Jenderal Soedirman, Purwokerto, Indonesia \\ ${ }^{2}$ Department of Pediatrics, Faculty of Medicine, Universitas Jenderal Soedirman, Purwokerto, Indonesia
}

Submitted: December 02 ${ }^{\text {nd }}$ 2018; Revised: November 27 $7^{\text {th }}$ 2021; Accepted: February $01^{\text {st }} 2021$

\begin{abstract}
Keywords:
Abstract Posyandu (integrated health center) as a health information center

KIA book

for the community is expected to be the spearhead of early detection of

Early detection developmental disorders in children under five. Posyandu activities are driven

Cadre training by cadres. Cadres monitor the growth of children under five through Integrated anthropometric measurements: body weight, height, head circumference and health center development milestones. Knowing how to measure anthropometric Growth and development parameters, data plotting on a growth chart in the Maternal and Child Health (Kesehatan Ibu dan Anak=KIA) book, and interpret the results are very important. Cadres with good understanding and skills will greatly assist in monitoring child growth and development. This activity is expected to increase the knowledge and skills of cadres in monitoring child development. This activity was carried out through counseling, training, case study, and discussion. Pre-tests and post-tests were conducted to evaluate this activity. The mean pre-test was $40.00 \pm 11.69$, with the lowest value being 10.00 and the highest value being 60.00 . The mean post-test was $54.10 \pm 12.08$, the lowest value was 30.00 and the highest was 90.00 . The Wilcoxon test found $p=000$, where $20.5 \%$ participants' knowledge did not change while $69.23 \%$ had better knowledge compared to before the activity. Conclusion: This training can significantly improve cadres' knowledge and skills about the use of the KIA book.
\end{abstract}

\section{INTRODUCTION}

Children are the future generation who determine a nation's future. The good quality of children is a step in creating a bright future for a nation (Depkes, 2008; Kosim, Santosa, \& Sudarmanto, 2009; Santosa et al., 2019). Experts on child development agree that the first two years of a child's is the golden period or critical period (Iswarawanti, 2010). At the age of five, the size of a child's brain is $90 \%$ of an adult's (Soedjatmiko et al., 2017). This is the period where children undergo rapid growth and development in which their brains are highly susceptible to stimuli from their surrounding environment (Diana, 2010; Susanto, 2018; Hairunis, Salimo, \& Dewi, 2018).

Yamin and Sabri (2013) stated that toddlers' brains during the first five years are susceptible to many stimuli, both positive and negative. Therefore, this period must be utilized to give guidance and positive values as well as adequate nutritional intake for the children (Susanto, 2018; Hairunis, Salimo, \& Dewi, 2018). In addition, good stimulation and healthcare service must be provided for the children during this period (Soetjiningsih, 2012). Due to the first five years being a relatively short period which can only happen once in the children's lifetime, everyone, including the

ISSN 2460-9447 (print), ISSN 2541-5883 (online)

${ }^{*}$ Corresponding author: Alfi Muntafiah

Faculty of Medicine Universitas Jenderal Soedirman Purwokerto, Jl. Dr. Gumbreng Purwokerto, Central Java 53112, Indonesia

Email: : alfimuntafiah99@gmail.com 
parents, caregivers, tutors, and healthcare personnel, including posyandu (integrated health center $=$ IHC) cadres, must utilize this short period especially during the first two years of the children's lives, to reinforce the children.

The effort of forming strong and excellent future generations can be done by observing and making sure that each period of a child's growth goes well (Moersintowati, 2000). The quality of a child can be determined by their growth. The assessment of the child's growth begins at an early stage when the child is born. Early detection of growth problems is done to find growth problems in toddlers at an early stage and determining their risk factors. Stimulation, intervention, healing, and recovery can be done at an early stage with a clear indication, and in accordance with their age if the growth problem was also found at an early stage (Depkes, 2012). If the child's growth problem is discovered late during development, it will be much harder to interfere thus affecting the child's growth in the future (Depkes, 2008).

The detection of growth problems on children can be done by any part on any level of healthcare system, from the family, primary health center (posyandu/health cadres), midwife, doctors, and medical specialists. As a form of community participation under the Department of Health, posyandu is an implementation of basic health screening and observation. The liveliness of posyandu is determined by its cadres. Thus, the cadres hold important roles in the children's growth and development (Depkes, 2012).

One of the posyandus which are active in providing health service is a posyandu in Rempoah Village, Baturaden Sub-district, Banyumas District. The posyandu activity in Rempoah Village includes providing food supplements, anthropometric measurements, body weight measurement, height measurements, head circumference measurement, and measurement recording. Anthropometric measurement should not only be recorded in books but should also be plotted on the corresponding graph (body weight according to age, height according to age, body weight according to length, and head circumference graph) (Iswarawanti, 2010). Those graphs are available in Maternal and Child Health (Kesehatan Ibu dan Anak= KIA) book. Therefore, posyandu cadres must be able to comprehend and retain how to measure anthropometric parameters correctly, how to plot the data on the growth graph found in KIA, and interpret the data in the plot (Iswarawanti, 2010). Competent posyandu cadres will be helpful in observing the growth and development of children.

\section{PROBLEM}

Based on the previous observation, it is known that the problems found in posyandu in Desa Rempoah, is the sub-optimal utilization of KIA book as a means of early detection of child growth defect. The anthropometric data based on the childrens' body weight, height, and head circumference has not been plotted into growth graph in KIA book thus the growth trend cannot be interpreted. In addition, the observation of growth aspect has not been conducted. Such problems also occurred in many posyandu in Banyumas (Zaki, Farida \& Sari, 2018).

\section{METHOD}

\subsection{Method, location, time, and duration of problem-solving activity}

This activity was held in Rempoah Village, Baturaden Sub-district, Banyumas District. The participants are the cadres of Posyandu Bina Kasih I-XI. The problem in this posyandu is the sub-optimal utilization of KIA book to detect child growth problems in their early stage. The effort to solve the problem can be done through education and training for the cadres (Muntafiah et al., 2018). The method uses to convey the materials are socialization, training, case exposure, and discussion. The socialization method was to convey the materials on the children's growth and development and how to detect growth problems at early stages. Training was done using the practice of measuring body weight, height, and head circumference properly and plotting the result in a normal growth graph included in Kartu Menuju Sehat (KMS) or Health Orientation Card and KIA book. Each participant was given a KIA book and as well as guidance on how to fill them. After data plotting, the participants were trained to interpret the result. The examples of cases also provided to ease the understanding of participants on the material.

\subsection{Data collection and analysis}

The participants' knowledge was assessed using pretest and post-test. The pre-test was done to know the initial knowledge of the participants before the activity. On the other hand, a post-test was done to measure participants' knowledge after the activity. Data analysis was done through a statistical test using SPSS 22 for Windows.

\section{RESULT AND DISCUSSION}

This activity was attended by the community engagement team, government officials of Rempoah Village, midwives, and cadres of Posyandu Bina Kasih I-XI Rempoah (Figure 1, Figure 2). The posyandu cadres held a special role in this activity due to them being the community members who have the strategic role as the primary driving force of the whole activity in posyandu (Megawati \& Wiramihardja, 2019). Posyandu cadres participate and work under the Department of Health as a basic means to observe the community's health. 
The fundamental problem found in posyandu was the lack of knowledge by the cadres from an academic and technical standpoint. Therefore, improvement of their knowledge and skill was needed to hold the posyandu activity according to the norm, standard, and procedure and deliver optimum service. Regarding child growth, the cadres had to be equipped with the proper skills on measuring children's body weight, height, head circumference, as well as observing the toddlers' development (Kemenkes, 2012; Kemenkes, 2015; Megawati \& Wiramihardja, 2019).

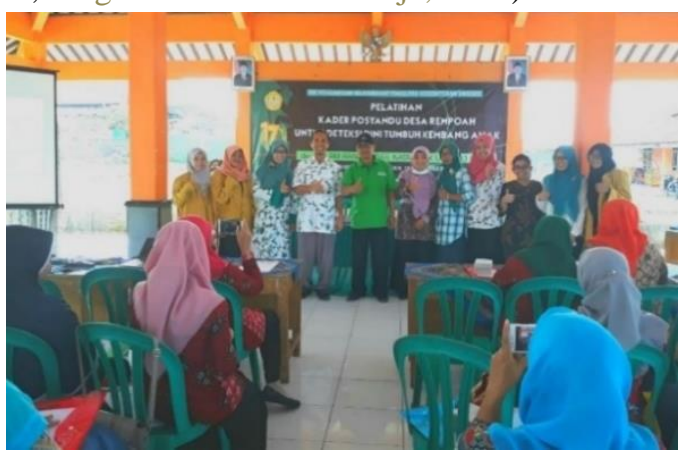

Figure 1. Community engagement team alongside the government representatives of Rempoah Village, housewife (Mrs. Munikmah, Amd.), and leader of posyandu cadres of Posyandu Bina Kasih (Mrs. Ratna Dewi Kristiani)

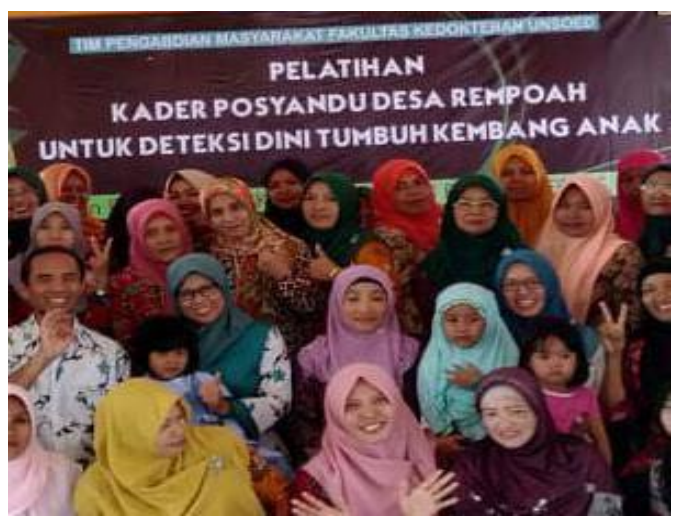

Figure 2. The team from Department of Health Unsoed alongside training participants

The activity began by registering the participants and distributing the questionnaire. Based on the questionnaire, the characteristic of the posyandu cadres in Desa Rempoah can be concluded. According to age, $42 \%$ of cadres are between the age of 27 to 40 years old; $40 \%$ of them are between 41 to 50 years old and $16 \%$ of them are above 51 years old. Most of the cadres $(59.5 \%)$ had been cadres for \pm 1 to 3 years; $11.9 \%$ of them had been cadres for 3 to 10 years, and $28.6 \%$ had been cadres for more than 10 years. The majority of the cadres $(90.5 \%)$ were housewives and the rest of them (9.5\%) were vendors. The posyandu cadres in Rempoah Village were active cadres. The $85.8 \%$ of the cadres always attended the training sessions from the local primary health clinic. Based on that data, it was known that housewives had a crucial role as the main forces in creating a healthy community. The housewives in
Rempoah Village not only acted as the target for health programs but also performers of programs who worked voluntarily for their country. Every month, the cadres who were housewives have to conduct a health checkup on the toddlers and senior citizens and compile the health data in their village (Wicaksono, 2016).

The main activity of this event is the training and socialization on children's growth by the speaker, Dr. dr. Qodri Santosa, M.Si. Med, Sp.A (Figure 3) assisted by the community engagement team as the facilitator. In this activity, the participants were given the KIA book by the facilitator. The speaker guided the cadres on how to fill the growth graph in the KIA books. Thus, the trend of a child's growth (increasing or not increasing) can be observed by plotting the anthropometric measures to the graph and connecting the dots in each month to make a growth line (Kemenkes, 2017).

The KIA books also facilitate the detection of growth problems at an early stage by looking at their signs and symptoms. The speaker explained the importance of surveillance on child growth by filling the checklist on the development abilities a child should have at their age, from the age of $0-3$ months, 3-6 months, 6-12 months, and forward ( $1-6$ years). The speaker explained that a child must be stimulated and trained if they have not acquired a milestone in the assessment list according to their age. If the child is unable to perform a developmental milestone after stimulation and training, the child must be brought to a health facility for further evaluation and treatment. Regarding the observation of a child's growth, in this activity, the participants were given training on the parameter on growth measurement including the measurement of body weight, height, and head circumference (Depkes, 2012). The measurement must result in valid data. The validity of the data measured by the cadres is crucial as they determine the children's growth, thus the next step can be decided.

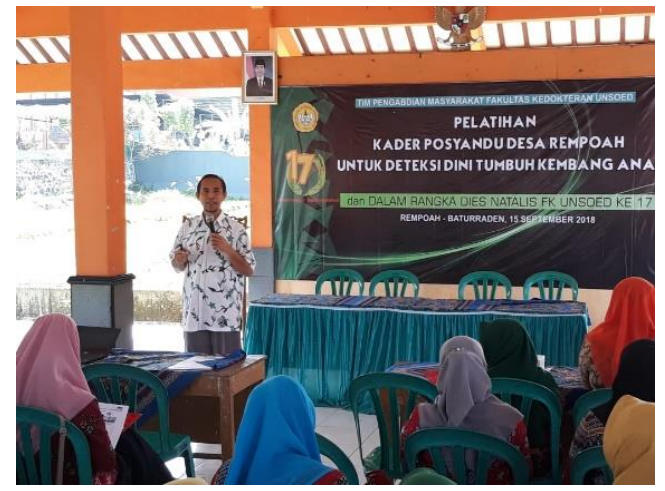

Figure 3. Lecture on early detection of children's growth problems by speaker (Dr. dr. Qodri Santosa, M.Si. Med, Sp.A)

Aside from socialization, training for recording data in KIA books, and measuring body weight, height, and head circumference, the speaker also gave case 
illustrations as examples in order for the participants understand better how to plot and connect the previous measurements as well as interpret the test result. In addition, the speaker stated that the plotting of premature babies has to be corrected. For instance, for a prematurely born infant who was born on the $36^{\text {th }}$ week of pregnancy, plotting of KMS data and other growth graphs cannot be conducted. The better option is to plot according to the estimated date of delivery.

The participants' understanding before and after the activity were measured using pre-test and post-test. The pre-test was done to measure the participants' initial knowledge before the activity. On the other hand, post-test was done to measure the participants' knowledge after the activity. The cadres' knowledge data can be seen in Table 1 .

Table 1. Analysis result of cadres' knowledge before and after training

\begin{tabular}{|c|c|c|c|c|}
\hline Variable & $\mathrm{N}$ & $\begin{array}{c}\text { Medium } \\
\text { (minimum- } \\
\text { maximum) }\end{array}$ & $\begin{array}{c}\text { Average } \\
\pm \mathrm{SD}\end{array}$ & $p$ \\
\hline $\begin{array}{l}\text { Knowledge } \\
\text { before } \\
\text { training }\end{array}$ & 39 & $\begin{array}{c}40(10- \\
60)\end{array}$ & $\begin{array}{l}40,00 \pm \\
11,69\end{array}$ & 0,000 \\
\hline $\begin{array}{l}\text { Knowledge } \\
\text { after training }\end{array}$ & 39 & $\begin{array}{c}50(30- \\
90)\end{array}$ & $\begin{array}{l}54,10 \pm \\
12,08\end{array}$ & \\
\hline
\end{tabular}

Based on the Wilcoxon test result, it was known that 8 participants maintained the same level of knowledge, while the other 27 have increased their understanding compared to before being trained. The Wilcoxon test provided the significance $\mathrm{p}=0,000$, thus it can be concluded that there is a significant difference in the participants' understanding before and after the activity.

\section{CONCLUSION}

Activities that will increase the knowledge and skills of posyandu cadres are important in order to support their role in the community. Inadequate use of the $\mathrm{MCH}$ Handbook as a tool for early detection of disorders of child growth and development problem can be solved by various methods, including lectures, training, case illustrations, and discussions. The success of this activity is measured by pre-test and post-test. Based on the results of the activity, it can be concluded that there are significant differences in participant's knowledge between before and after participating in the activity. The next activity plan that will be carried out by the service team is direct assistance and monitoring of the implementation of posyandu activities for early detection of child development disorders.

\section{REFERENCE}

Departemen Kesehatan RI. (2008). Buku Kesehatan Ibu dan Anak. Gerakan Nasional Pemantauan Tumbuh Kembang Anak. Jakarta: Departemen Kesehatan RI.

Departemen Kesehatan RI. (2012). Pedoman Pelaksanaan Stimulasi, Deteksi dan Intervensi Dini Tumbuh Kembang Anak Tingkat Pelayanan Kesehatan Dasar. Jakarta: Departemen Kesehatan RI.

Diana, F.M. (2010). Pemantauan Perkembangan Anak Balita. Jurnal Kesehatan Masyarakat, 4(2), 116129. DOI: https://doi.org/10.24893/jkma.v4i2.7 9

Hairunis, M.N., Salimo, H., \& Dewi, Y.L.R. (2018). Hubungan Status Gizi dan Stimulasi Tumbuh Kembang dengan Perkembangan Balita. Sari Pediatri, 20(3),

$146-$ 151. DOI: http://dx.doi.org/10.14238/sp20.3.20 $18.146-51$

Iswarawanti, D.N. (2010). Kader Posyandu: Peranan dan Tantangan Pemberdayaannya dalam Usaha Peningkatan Gizi Anak di Indonesia. Jurnal Manajemen Pelayanan Kesehatan, 13(4), 169173.

Kementerian Kesehatan RI. (2017). Buku Kesehatan Ibu dan Anak. Jakarta: Kementerian Kesehatan RI dan JICA.

Kementerian Kesehatan RI. (2012). Kurikulum dan Modul Pelatihan Fasilitator Pemberdayaan Kader Posyandu. Sekretariat Jenderal Pedoman Umum Pengelolaan Posyandu, Jakarta.

Kementerian Kesehatan RI. (2015). Petunjuk Teknis Penggunaan Buku KIA. Departemen Kesehatan RI, Jakarta.

Kosim, M.S., Santosa, Q., Sudarmanto, B. (2009). Pengaruh Waktu Penjepitan Tali Pusat terhadap Kadar Hemoglobin dan Hematokrit Bayi Baru Lahir. Sari Pediatri, 10(5), 331337. DOI: http://dx.doi.org/10.14238/sp10.5.20 09.331-7

Megawati, G. \& Wiramihardja, S. (2019). Peningkatan Kapasitas Kader Posyandu dalam Mendeteksi dan Mencegah Stunting di Desa Cipacing Jatinangor. Jurnal Aplikasi Ipteks untuk Masyarakat, 8(3), $\quad$ 154-159. DOI : https://doi.org/10.24198/dharmakarya.v8i3.20 726

Moersintowati, B.N. (2000). Deteksi Dini Tumbuh Kembang. Simposium Penatalaksanaan

Mutakhir Bidang Ilmu Kesehatan Anak Mencapai Tumbuh Kembang Optimal. Bandung: IDAI Jawa Barat.

Muntafiah, A,. Afifah, Sari, O.P., Harini, I.M., \& Santosa, Q. (2018). Promosi Kesehatan untuk Mencegah Miopi dan Komplikasinya pada Murid SD N 2 Berkoh, Purwokerto. Jurnal Pengabdian Pada Masyarakat, 3(1), 21-26. DOI: https://doi.org/10.30653/002.201831.48

Santosa, Q., Ferine, M., Fakih, M., \& Muntafiah, A. (2019). Pelatihan Manajemen Laktasi untuk Ibu 
Hamil dan Ibu Menyusui: Upaya Optimalisasi Tumbuh Kembang Anak. Jurnal Pengabdian Pada Masyarakat, 4(1), 4752. DOI:10.30653/002.201941.94

Soedjatmiko, S., Gunardi, H., Sekartini, R., Medise, B.E., Ikhsan, Wibowo, Y. et al. (2017). Efektivitas Seminar pada Perubahan Sikap Ibu dalam Pemberian Dukungan Nutrisi dan Stimulasi Selama Pemantauan Tumbuh Kembang. Sari Pediatri, 19(4), 201208. DOI: http://dx.doi.org/10.14238/sp19.4.20 17.201-8

Soetjiningsih. (2012). Tumbuh Kembang Anak. Jakarta: EGC. Penerbit Buku Kedokteran.

Susanto, J.C. (2018). The Roles of Nutrition in Children Growth and Development. Continuing Professional Development (CPD X) "Update In Pediatric Practice Problem". Semarang: Penerbit FK UNDIP, ISBN: 9786025560668.

Wicaksono, M.A. (2016). Ibuisme Masa Kini: Suatu Etnografi tentang Posyandu dan Ibu Rumah Tangga. Indonesian Journal of Anthropology, 1(2), 125137. DOI: https://doi.org/10.24198/umbara.v1i2 .9921

Yamin, M. \& Sabri, J.S. (2013). Panduan Lengkap PAUD Melejitkan Potensi dan Kecerdasan Anak Usia Dini. Ciputat: Gaung Persada.

Zaki, I., Farida, F. \& Sari, H. P. (2018). Peningkatan Kapasitas Kader Posyandu melalui Pelatihan Pemantauan Status Gizi Balita. Jurnal Pengabdian kepada Masyarakat (Indonesian Journal of Community Engagement), pp. 169177. 